\title{
Design of a DC Microgrid System for a Remote Community in Nigeria
}

\author{
Japhet Ozogbuda and M. Tariq Iqbal
}

\begin{abstract}
This paper presents the design of a DC microgrid for a remote community in Edo State, Nigeria having a solar irradiance of $4.63 \mathrm{kWh} / \mathrm{m}^{2} / \mathrm{day}$. The community is isolated and located far away from the city with no access to the electricity grid. There is a need for lighting and running of electronics, as the main source of lighting presently is kerosine, which is not efficient and leads to health issues. The community is made up of 9 residences that are not more than $100 \mathrm{~m}$ apart. House 1 was selected as the standard house with a load of $1 \mathrm{kWh} / \mathrm{day}$, while the other 8 houses have a load difference of $\pm 10 \%$ with reference to house 1. Using a $48 \mathrm{~V}$ DC bus, the designed PV system components comprise of a $100 \mathrm{~W}$ solar photovoltaic $(\mathrm{PV})$ panel and a 12 V $45 \mathrm{~A} \cdot \mathrm{hr}$ battery. The system was sized using Homer Pro. Optimization results presented various design for the various houses. The result obtained showed reasonable and feasible cost-effective solution in terms of the Net Present Cost in both installation and running of the hybrid system for the community. Sensitivity analysis was also carried out to test the adaptability of the system using a solar irradiation input of $\pm 10 \%$. Detailed result of the analysis is presented in the paper.
\end{abstract}

Keywords - Homer Pro; Optimization; Solar energy; renewable energy.

\section{INTRODUCTION}

The problems faced in increasing electrification are infrastructure and distribution of power plants, especially in remote areas [1]. Lack of electricity in most African countries has been an issue that is yet to be resolved, Nigeria is not an exception from this situation of lack of electricity/insufficient power supply. Most remote areas in the country suffer from a total electrical blackout for days and in worse cases, no access to electricity grid. In this remote area, Kerosine lantern is mostly used for lighting purpose. Due to the moderate temperature in these areas, there is usually no need for heating. Conventional approach to meet such needs is to connect these remote areas to the electrical grid, but this would be very expensive and unpractical because most of these remote residences are so far from the common cities that the line loss and maintenance cost would be too much and non-feasible to implement. Notwithstanding, Electricity is needed in this area for proper lighting and running of electronics.

Renewable energy is the most appropriate solution to supply energy in isolated areas. Utilization of locally available resources is the best possible option to meet the energy requirement. Single technology-based system (solar photovoltaic/wind/small hydro) is a viable option to supply

Submitted on November 15, 2021.

Published on December 13, 2021.

Japhet Ozogbuda, ECE, Faculty of Engineering, Memorial University of

Newfoundland, Canada. energy in isolated areas. Un-electrified rural areas like village hamlets or small villages that are far away from the utility grid can be electrified by single technology [2]. One solution that can be done is to build a power generation using off-grid power system. Off-grid power system can consist of PVBattery or Genset-Battery to supply the communal load [3]. STANDALONE Photovoltaic (PV) systems are designed and sized to supply certain AC and/or DC electrical loads [4].

Adithya designed a small off-grid PV system for a rural home. The system comprised of a $5 \mathrm{~W} \mathrm{PV}$, and a $6 \mathrm{~V}, 7 \mathrm{~A} \cdot \mathrm{h}$ lead acid battery. The system was used to power small loads like LED (Light emitting diode) lamp and mobiles. Simulation result shows the system was efficient in powering the resident [5]. Sini designed a system for a rural residence in Bhilai, Chhattigarh which experiences breakdown and tripping in power supply. The house has an estimated energy consumption of $30.41 \mathrm{kWh} / \mathrm{d}$ and $3.24 \mathrm{~kW}$ peak power. Simulation was carried out using Homer Pro. The result showed that among other possible configuration, the PVbattery system has the lowest Net Present Cost (NPC) and $\mathrm{COE}$ and would yield reasonable returns in the long run [6]. Nunu designed a solar PV system for Mapetja rural village having a solar radiation of $5.96 \mathrm{kWh} / \mathrm{m}^{2}$. The village is located far away from the National grid. The total load consumption of a single house in the village was found to be approximately $11 \mathrm{kWh} / \mathrm{d}$. The PV system required for sufficient supply comprised of 728 modules ( 7 series, 104 parallel), a charge controller, 18 deep cycle batteries of $12 \mathrm{~V}$, and an inverter. Result showed that the use of the designed stand-alone PV system would be the best suitable sustainable solution for the village in terms of electricity supply [7]. Chin designed and optimised a PV hybrid system for the residential community of Basco island in the Philippines to replace the diesel generator only system. the proposed energy system is made up of $4611 \mathrm{~kW} \mathrm{PV}, 116$ batteries of $12823 \mathrm{kWh}$, $10 \mathrm{kWh}$ wind generators, $1000 \mathrm{~kW}$ diesel generator, and $1500 \mathrm{~kW}$ converter. The system was found to be both power efficient enabling the use of electricity supply for 24-hours and cost-effective with the cost of energy (COE) equals to $\$ 0.409 / \mathrm{kWh}$ for $\$ 1 /$ litre diesel fuel cost [8].

Chaudry proposed an off-grid PV system for a house in Pakistan having a load of $7.81 \mathrm{kWh} /$ day, the system comprised of 8 batteries and 36 PV. From the design, simulated results showed that the configuration is sufficient enough to power the house efficiently independently from the national grid [9]. Arif carried out a design for an off-grid solar system for a house with average energy consumption of 40

M. Tariq Iqbal, ECE, Faculty of Engineering, Memorial University of Newfoundland, Canada. 
$\mathrm{kWh}$ per month located in a remote community in Pakistan, the system comprised of 4 solar panels of $140 \mathrm{~W}$, giving a total of $560 \mathrm{~W} \mathrm{PV}, 4$ batteries each having $125 \mathrm{~A} \cdot \mathrm{hr}$ and a $1 \mathrm{~kW}$ inverter. The result showed the system provided a better electrification solution with an energy production of $726 \mathrm{kWh}$ per annum [10].

The selected site is located using the google earth pro, with coordinates $(6.182863,5.933505)$ Latitude: $6^{\circ} 10^{\prime} 58.3^{\prime \prime} \mathrm{N}$ Longitude: $5^{\circ} 56^{\prime} 00.6^{\prime \prime E}$. Having a solar irradiance value of $4.63 \mathrm{kWh} / \mathrm{m}^{2} /$ day. The community is made up of 9households which are completely cut off from the utility grid. The houses are not more than $100 \mathrm{~m}$ apart as shown in Fig. 1.

The purpose of this research is to design a system where each house has a photovoltaic (PV) panel and a battery. The loads are all connected with a $48 \mathrm{~V}$ bus. All loads are DC loads. The sizing of the system has been done using the Homer Pro optimization software. Smaller loads are supplied through $48 \mathrm{~V}$ to $12 \mathrm{~V}$ and $48 \mathrm{~V}$ to $5 \mathrm{~V}$ DC-DC converters

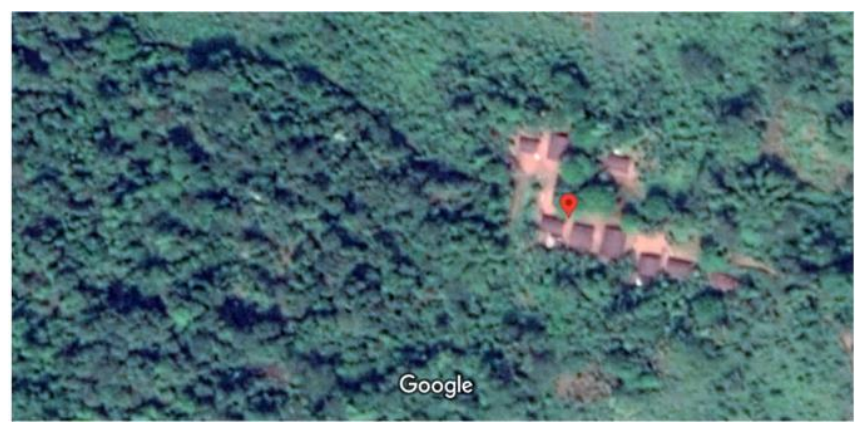

Fig. 1. Location of the remote community in Nigeria.

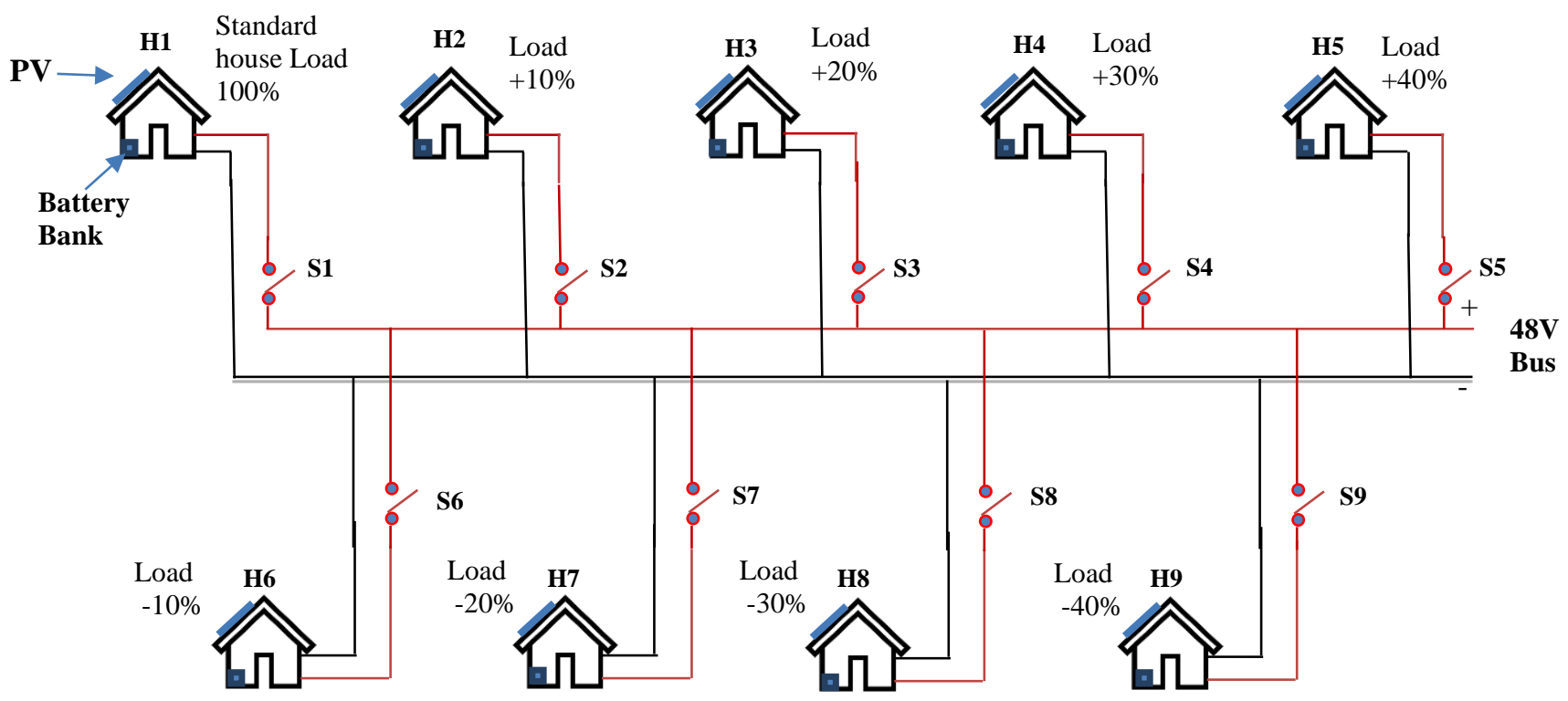

Fig. 2. block diagram showing load distribution of households in the community.

\section{SYSTEM COMPONENT DESIGN}

The system comprises a Donghui High efficiency $100 \mathrm{~W}$ Mono solar panel, and a PowerStar battery of $12 \mathrm{~V}, 45 \mathrm{~A} \cdot \mathrm{hr}$ all connected to the $48 \mathrm{~V}$ bus, there is no inverter in the system. the MPPT ensures the PV reaches maximum powerpoint. House load is $48 \mathrm{~V} / 12 \mathrm{~V} / 5 \mathrm{~V}$. Two DC-DC converters are used to get $12 \mathrm{~V}$ and $5 \mathrm{~V}$ from $48 \mathrm{~V}$. TV and some lights are $48 \mathrm{~V}$. Some lights and fan run on $12 \mathrm{~V}$. Radio/cell phone needs $5 \mathrm{~V}$ for charging.

\section{ELECTRICAL LOAD}

Each household in the community has a few loads to be powered, comprising mostly of lighting points, table fan, radio, and TV. A detailed breakdown of a load of each household is presented in Table I below. Some residents have cell phones that they take to nearby villages for charging.

TABLE I: DAILY ENERGY REQUIREMENT FOR HOUSE 1 IN THE COMMUNITY

\begin{tabular}{cccccc}
\hline \hline Appliances & Quant. & Watt.(W) & Total(W) & $\begin{array}{c}\text { Usage } \\
\text { (hours) }\end{array}$ & $\begin{array}{c}\text { Energy } \\
\text { (Wh/day) }\end{array}$ \\
\hline LED bulb & 3 & 18 & 54 & 10 & 540 \\
Fan & 2 & 10 & 20 & 9 & 180 \\
Radio/cell & 1 & 5 & 5 & 8 & 40 \\
phone & 1 & 30 & 30 & 8 & 240 \\
$\begin{array}{c}\text { Television } \\
\text { Total: }\end{array}$ & 1 & & $\mathbf{1 0 9}$ & & $\mathbf{1 0 0 0}$ \\
\hline \hline
\end{tabular}

The figure below shows the percentage load distribution of the 9 households in the community for a converter less isolated DC microgrid. With house 1 as a reference and a load variation of $\pm 10 \%$, the load distribution from house 1 to house 9 are $1 \mathrm{kWh} /$ day, $1.1 \mathrm{kWh} /$ day, $1.2 \mathrm{kWh} /$ day, $1.3 \mathrm{kWh} /$ day, $1.4 \mathrm{kWh} /$ day, $0.9 \mathrm{kWh} /$ day, $0.8 \mathrm{kWh} /$ day, $0.7 \mathrm{kWh} /$ day and $0.6 \mathrm{kWh} /$ day. Each house has a PV system, a battery bank, and an ON/OFF switch to connect/disconnect from the microgrid if they decide to do so.
The system was designed in Homer Pro. Fig. 5 above represents the optimization result for the 9 houses with various electrical loads. Using a $100 \mathrm{~W}$ PV and $12 \mathrm{~V}, 45 \mathrm{~A} \cdot \mathrm{hr}$ lead acid battery, For the house with $0.6 \mathrm{kWh} / \mathrm{d}$ of load, the required components would be $0.417 \mathrm{~kW} \mathrm{PV}$ and 4 batteries. For the house with $0.7 \mathrm{kWh} / \mathrm{d}$ of load, the required components are: $0.323 \mathrm{~kW}$ PV and 8 batteries with this configuration come the highest autonomy of $88.9 \mathrm{hr}$, which means in the absence of solar power the backup battery can run for up to 4 days. For the house with $0.8 \mathrm{kWh} / \mathrm{d}$ of load, 
the required components are $0.396 \mathrm{~kW}$ and 8 batteries. For the household with $0.9 \mathrm{kWh} / \mathrm{d}$ of load consumption, the required components include $0.863 \mathrm{~kW} \mathrm{PV}$ and 4 batteries. For a house with $1.10 \mathrm{kWh} / \mathrm{d}$ of energy consumption, required components: $1.21 \mathrm{~kW} \mathrm{PV}$ and 4 batteries. For a house with $1.20 \mathrm{kWh} / \mathrm{d}$ of load, the required components are $0.827 \mathrm{~kW}$ PV and 8 batteries. For a house with $1.30 \mathrm{kWh} / \mathrm{d}$ of load, the required components would be $0.958 \mathrm{~kW}$ PV and 8 batteries. For the house with $1.4 \mathrm{kWh} / \mathrm{d}$ of load, the required components are $0.759 \mathrm{~kW}$ PV and 12 batteries. For the house with $1 \mathrm{kWh} / \mathrm{d}$ of load, the required components are $0.576 \mathrm{~kW}$ PV and 8 batteries. All houses show a renewable fraction of $100 \%$ and the initial cost, capital cost, and operational cost vary from one house to another. Say a house needs $0.759 \mathrm{~kW}$ PV and each PV module is $100 \mathrm{~W}, 12 \mathrm{~V}$ then four modules will be used in series ( $800 \mathrm{~W}$ total) to have a $48 \mathrm{~V}$ system. Small PV modules and batteries were selected that could be carried and moved around without any need for a vehicle and road that does not exist in the community.

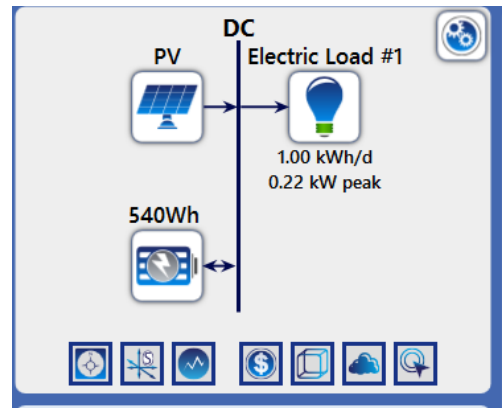

Fig. 3. Homer Pro system block diagram.

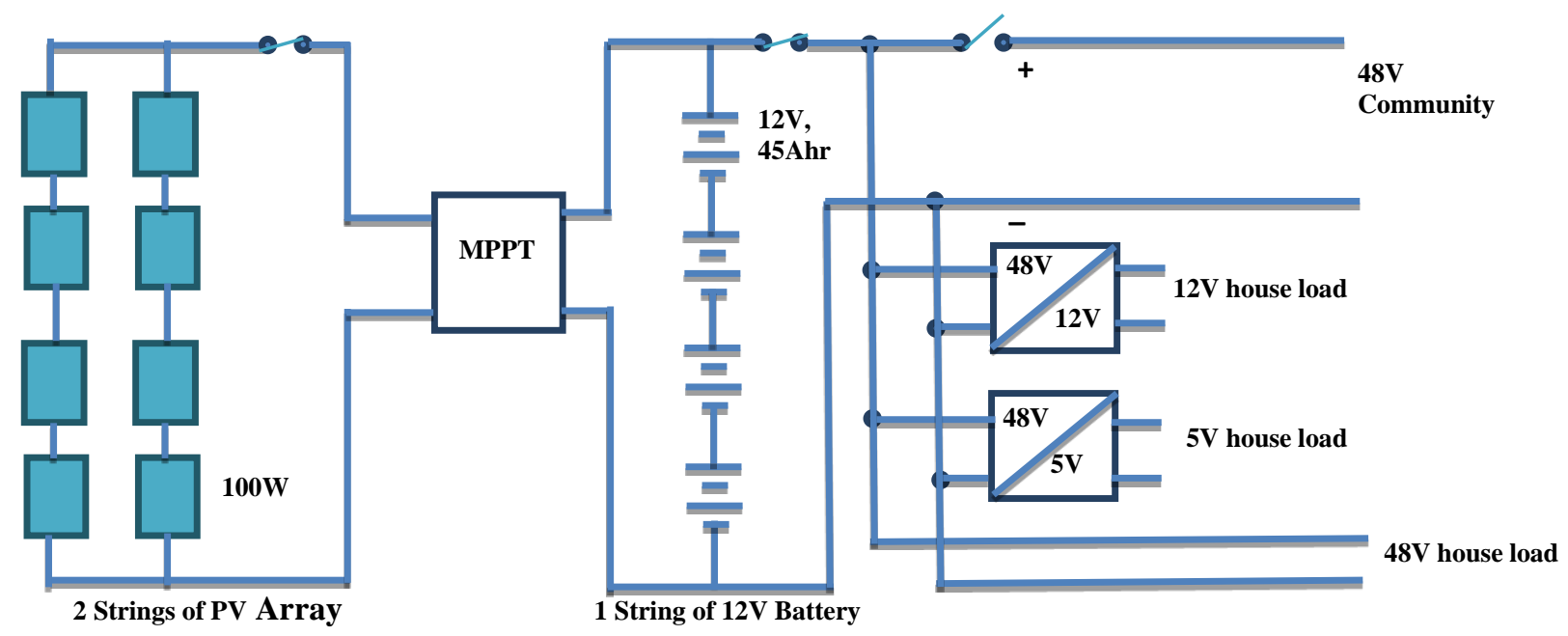

Fig. 4. System component in a house.

\begin{tabular}{|c|c|c|c|c|c|c|c|c|c|c|c|c|c|c|c|}
\hline \multirow{2}{*}{$\begin{array}{c}\text { Sensitivity } \\
\begin{array}{l}\text { Electric Load \#1 } \\
\text { Scaled Average } \\
\text { (kWh/d) }\end{array}\end{array}$} & \multicolumn{5}{|c|}{ Architecture } & \multicolumn{4}{|c|}{ Cost } & \multicolumn{2}{|c|}{ System } & \multicolumn{2}{|c|}{ PV } & \multicolumn{2}{|r|}{$540 \mathrm{Wh}$} \\
\hline & $m$ & 자잔 & $\begin{array}{l}\mathrm{PV} \\
(\mathrm{kW})\end{array}$ & 540Wh $\nabla$ & Dispatch $\nabla$ & $\begin{array}{l}\mathrm{NPC} \\
\text { (US\$) }\end{array}$ & $\left.\begin{array}{l}\mathrm{COE} \\
\text { (US\$) }\end{array}\right] \nabla$ & $\begin{array}{c}\text { Operating cost } \\
\text { (US\$/yr) }\end{array}$ & 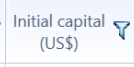 & $\begin{array}{c}\text { Ren Frac } \\
(\%)\end{array}$ & $\begin{array}{c}\text { Total Fuel } \\
(\mathrm{L} / \mathrm{yr})\end{array}$ & $\begin{array}{c}\text { Capital Cost } \nabla \\
\text { (US\$) }\end{array}$ & $=\begin{array}{l}\text { Production } \\
(\mathrm{kWh} / \mathrm{yr})\end{array}$ & $\begin{array}{l}\text { Autonomy } \nabla \\
\text { (hr) }\end{array}$ & $\begin{array}{c}\text { Annual Through } \\
(\mathrm{kWh} / \mathrm{yr})\end{array}$ \\
\hline 0.600 & 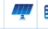 & 国 & 0.417 & 4 & $C C$ & $\$ 2,407$ & $\$ 0.851$ & $\$ 108.49$ & $\$ 1,004$ & 100 & 0 & 304 & 569 & 51.8 & 131 \\
\hline 0.700 & $m$ & 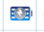 & 0.323 & 8 & $\mathrm{CC}$ & $\$ 3,780$ & $\$ 1.15$ & $\$ 165.90$ & $\$ 1,636$ & 100 & 0 & 236 & 440 & 88.9 & 160 \\
\hline 0.800 & $m 8$ & 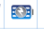 & 0.396 & 8 & $C C$ & $\$ 3,928$ & $\$ 1.04$ & $\$ 173.22$ & $\$ 1,689$ & 100 & 0 & 289 & 540 & 77.8 & 182 \\
\hline 0.900 & 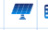 & 중 & 0.863 & 4 & $C \mathrm{C}$ & $\$ 3,310$ & $\$ 0.780$ & $\$ 153.13$ & $\$ 1,330$ & 100 & 0 & 630 & 1,178 & 34.6 & 191 \\
\hline 1.10 & 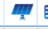 & 중 & 1.21 & 4 & $\mathrm{CC}$ & $\$ 4,015$ & $\$ 0.774$ & $\$ 188.00$ & $\$ 1,585$ & 100 & 0 & 885 & 1,654 & 28.3 & 231 \\
\hline 1.20 & $m$ & 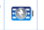 & 0.827 & 8 & $C C$ & $\$ 4,799$ & $\$ 0.848$ & $\$ 216.29$ & $\$ 2,003$ & 100 & 0 & 603 & 1,128 & 51.8 & 263 \\
\hline 1.30 & $m$ & 중 & 0.958 & 8 & CC & $\$ 5,066$ & $\$ 0.827$ & $\$ 229.47$ & $\$ 2,100$ & 100 & 0 & 700 & 1,308 & 47.9 & 283 \\
\hline 1.40 & $m$ & 중 & 0.759 & 12 & $\mathrm{CC}$ & $\$ 6,226$ & $\$ 0.943$ & $\$ 276.33$ & $\$ 2,654$ & 100 & 0 & 554 & 1,036 & 66.7 & 314 \\
\hline 1.00 & $m 8$ & 중 & 0.576 & 8 & CC & $\$ 4,293$ & $\$ 0.911$ & $\$ 191.27$ & $\$ 1,821$ & 100 & 0 & 421 & 787 & 62.2 & 223 \\
\hline
\end{tabular}

Fig. 5. System design for each house in the community.

\section{ECONOMIC ANALYSIS}

Homer Pro also performs economic analysis to determine the feasibility of implementing the system with financial considerations. The cost summary of the simulated result shows the detailed breakdown of the cost of the system which comprises the capital cost, replacement cost, operation, and maintenance (O\&M) cost, salvage cost, and total cost of each component. The total cost of all the components gives the Net Present Cost (NPC) of the system per household. Table II below provides all cost details for all houses in the community.

House 9 with an electrical load of $0.6 \mathrm{kWh} / \mathrm{d}$, Homer Pro analysis shows that the Net Present Cost (NPC) for installation, operation and running of this system is $\$ 2,407$, initial capital cost of $\$ 1,004$, operational cost of $\$ 108.49$. The Fig. 6 below shows the cost summary and breakdown of the cost for the components. Fig. 6 shows the cost summary of 
House 9. It also shows the capital cost, replacement cost, operational cost, salvage, and total cost for each component of the system. for the PV it shows a capital cost of $\$ 304.17$, operation and maintenance (O\&M) cost of $\$ 538.65$, and this gives a total cost of $\$ 842.81$. The Battery has a capital cost of $\$ 700$, the replacement cost of $\$ 401.08, \mathrm{O} \& \mathrm{M}$ cost of $\$ 517.10$, salvage cost of $\$ 54.38$, which gives a total cost of $\$ 1,563.80$. the total cost of both components (PV and battery) gives the NPC of the system. Information on capital costs, initial capital, operational cost, and NPC for other houses in the community can be found in Table II.

TABLE II: OPTIMIZED COST FOR EACH RESIDENCE IN THE COMMUNITY

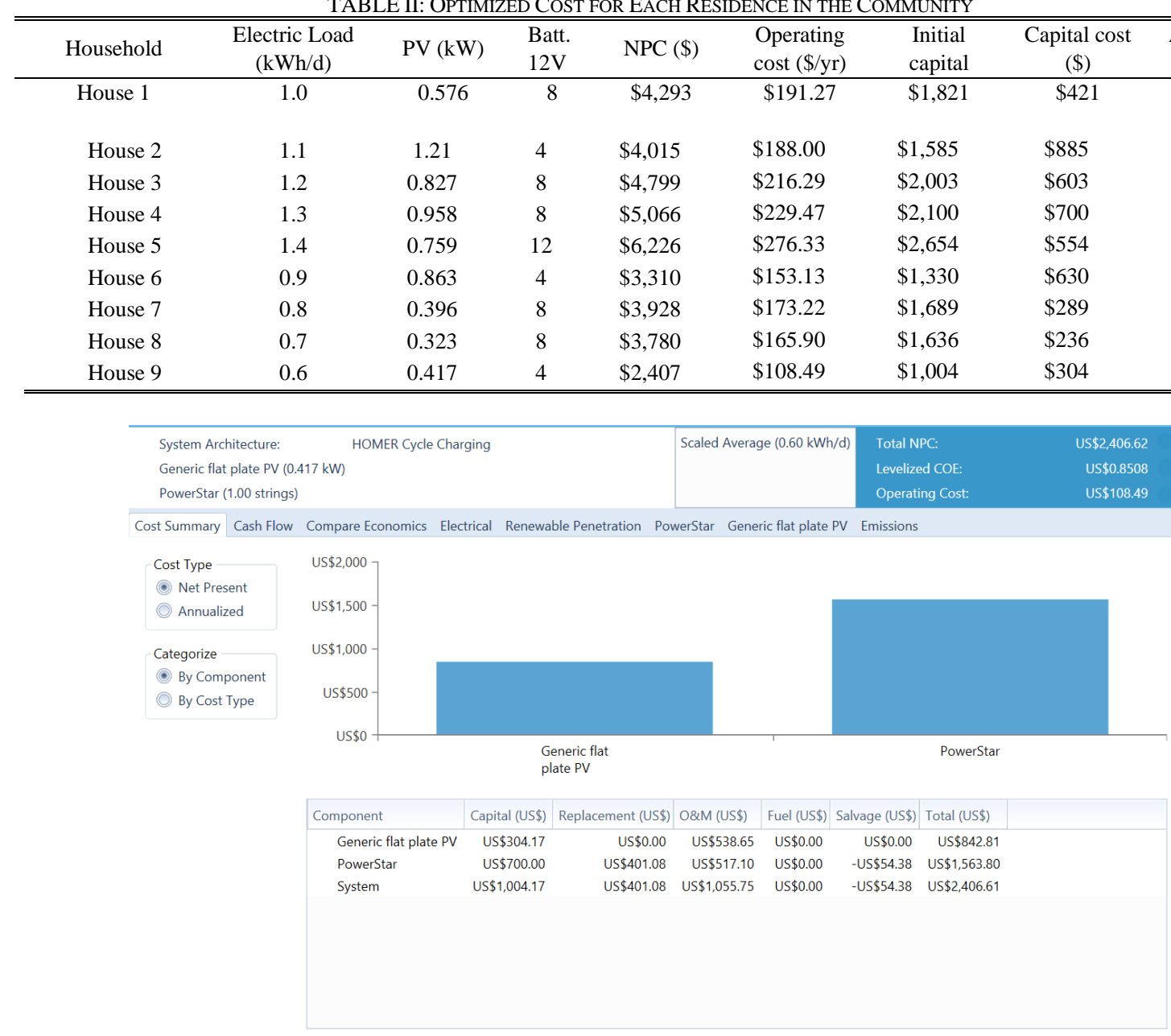

Fig. 6. Cost summary of house 9 .

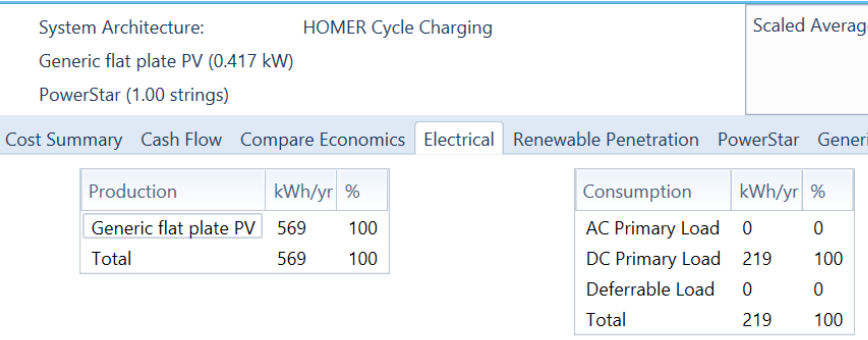

$\begin{array}{lr}\text { Total NPC: } & \$ 2,406.62 \\ \text { Levelized COE: } & \$ 0.8508 \\ \text { Operating Cost: } & \$ 108.49\end{array}$

utonomy

(hr)

51.8

47.9

6.7

34.6

77.8

88.9

51.8 


\section{ELECTRICAL OUTPUT}

Fig. 7 above shows the electrical output for house 1 having a load of $0.6 \mathrm{kWh} / \mathrm{d}$. the homer optimization result showed the most efficient system for the resident is $0.417 \mathrm{~kW}$ PV and 1 string of Power battery. For the PV component, a 12V 100 W PV was selected whereas for the battery a $12 \mathrm{~V}, 45 \mathrm{~A} \cdot \mathrm{hr}$ PowerStar battery was selected. The system has been simulated using a $48 \mathrm{~V}$ bus system, which will require 4 of the selected PV modules connected in series and 4 of the selected battery components connected in series to give 1 string of battery. The result also shows a $100 \%$ renewable fraction and excess electricity of $321 \mathrm{kWh} / \mathrm{y}$. Optimization result shows autonomy of the system to be $51.8 \mathrm{~h}$, which means in the case of no solar resource due to rainy days the battery system can supply power for up to 2 days. The monthly electrical production for the year is also shows the monthly production of PV power for the span of one year, the graph showed peak production in the months of January, March, November, and December, while the lowest production in the month of July (days are larger in July and house lighting needs are reduced).

Each house has a PV system that could be connected to the community DC microgrid through a switch. In the selected community of PV system with no measurement system is difficult to maintain due to poor know-how and lack of knowledge. Battery may over discharge due to carelessness. If all houses are connected through DC microgrid then people can share excess production with neighbours and that will lead to a more reliable system. If a house owner forgot to clean PV modules, then for a time being power can come from neighbours. Therefore, a community system connected through $48 \mathrm{~V}$ bus as shown in Fig. 2 is recommended and designed.

Fig. 8 above also shows the hourly time series detailed analysis of the battery State of charge and the Solar PV power output for the span of 1 year. From the graph it can be deduced that the period of sharp decline in the state of charge of the battery from $100 \%$ to $40 \%$ is between the month of June to September, whereas the power output of the solar PV varies almost throughout the year. In a DC microgrid such sharp decline is less likely due to power sharing among neighbours.

\section{SENSITIVITY ANALYSIS}

Sensitivity analysis also called the "what if analysis" is critical in understanding the robustness of a design. It allows you to understand how a changing input will affect the choice of least cost system. In this design model, sensitivity analysis is performed on solar irradiation. Inputting a range of solar irradiation from $4.14 \mathrm{kWh} / \mathrm{m}^{2} /$ day to $5 \mathrm{kWh} / \mathrm{m}^{2} /$ day due to climate change factors such as less cloudiness in certain times of the year (summer/dry season) causes the solar irradiation to increase and dust accumulation on PV leads to decrease in PV efficiency.

Due to climate change factors such as less cloudiness in certain times of the year (summer/dry season) the solar irradiation increases, so therefore the optimization result also takes this variable into consideration by optimizing the system with a solar irradiation value of $5.00 \mathrm{kWh} / \mathrm{m}^{2} /$ day. The optimization result shows the different house loads and est possible configuration for optimal and efficient supply of power to the residence in the community. Fig. 9 below shows system sensitivity analysis results obtained from Homer Pro.

Fig. 9 above shows some of the sensitivity results for the community. For the house with a load of $0.6 \mathrm{kWh} /$ day, the sensitivity cases show three results: case 1 for solar irradiation of 4.14 , case 2 for solar irradiation of 4.63 and case 3 for solar irradiation of 5.00. from these three cases, it can be observed that as solar irradiation increases number and cost of components reduces. For example, for 4.14 solar irradiation the required component would be 4 batteries, $0.469 \mathrm{~kW} \mathrm{PV}$, and the NPC of the system would be $\$ 2,512$. Whereas, for the 5.00 solar irradiation case required components would involve 4 batteries and $0.385 \mathrm{~kW}$ PV, which shows an NPC of \$2,343. The same applies to all other sensitivity cases.

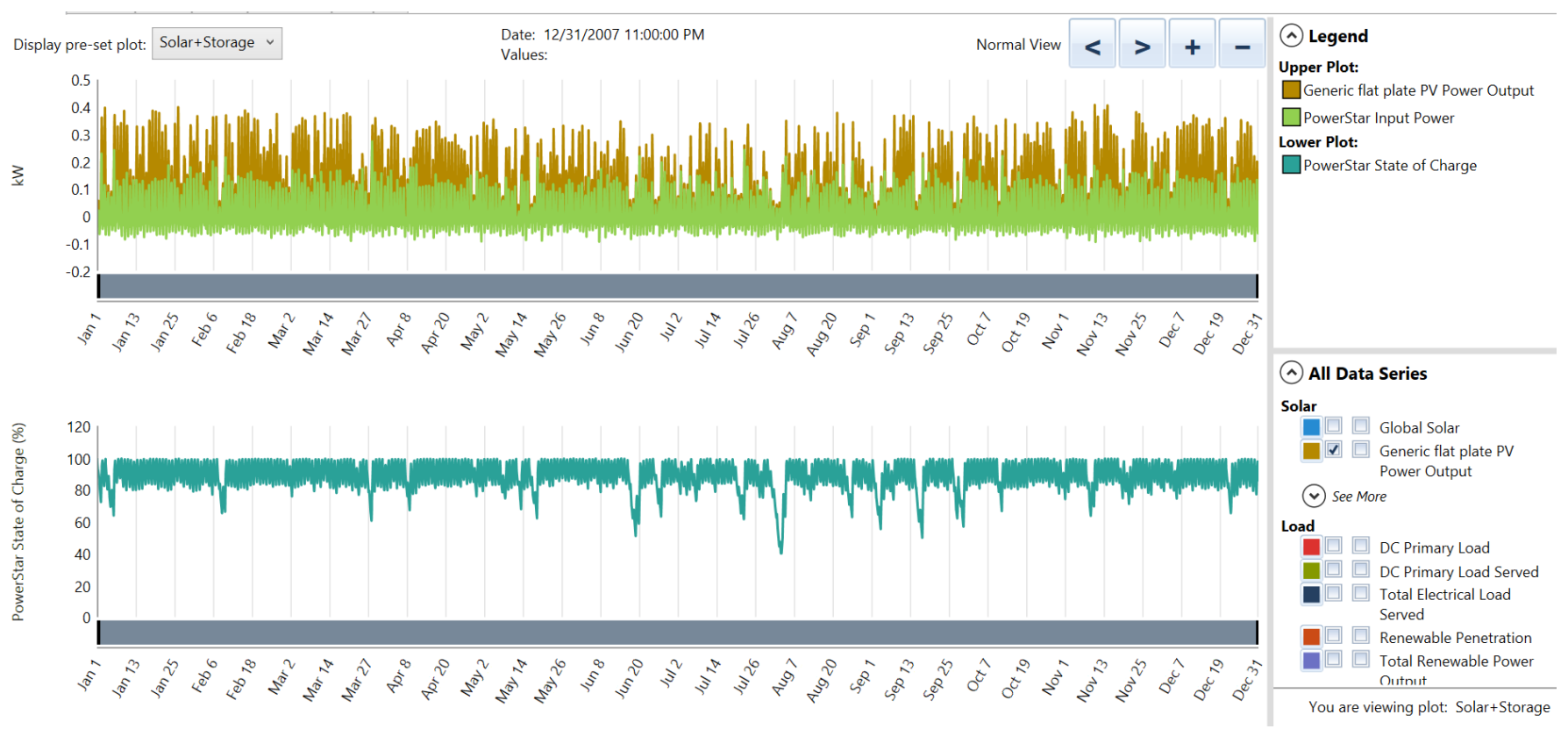

Fig. 8. Time series detail analysis of PV power output for a resident. 


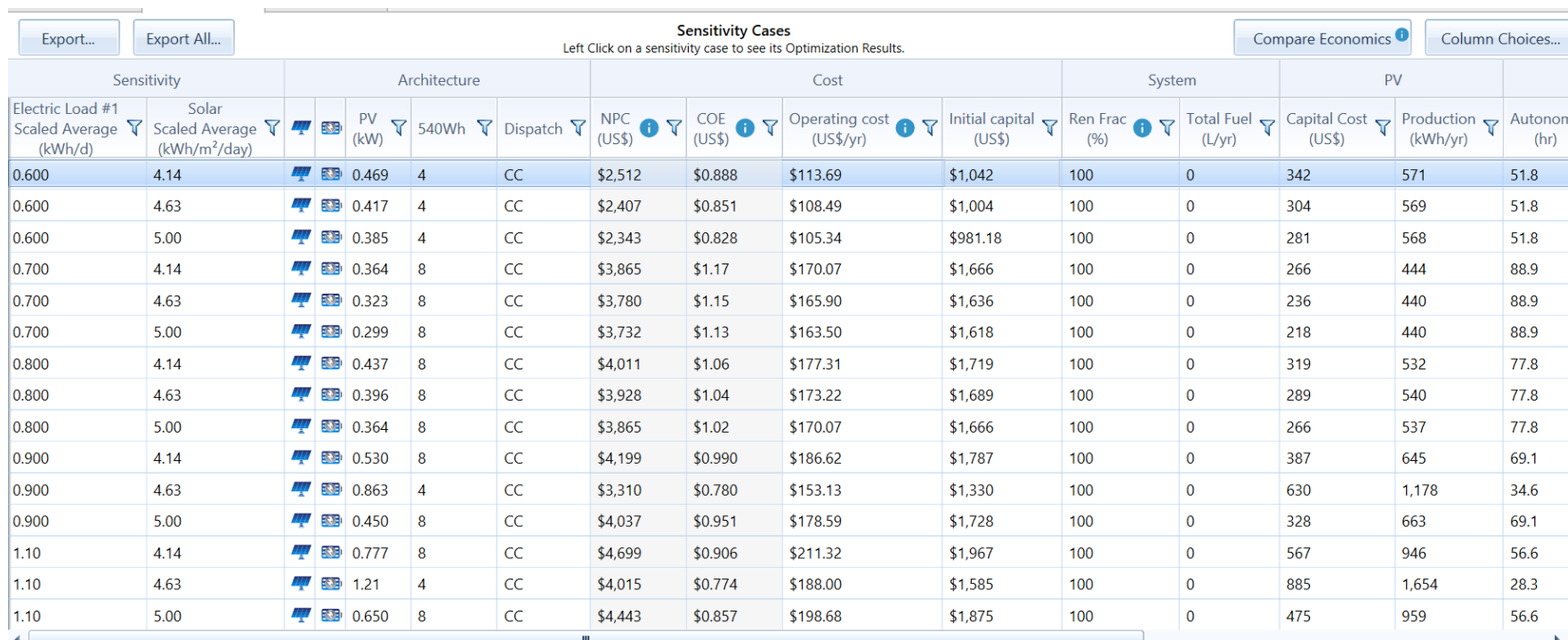

Fig. 9. Sensitivity analysis of system design in Homer Pro.

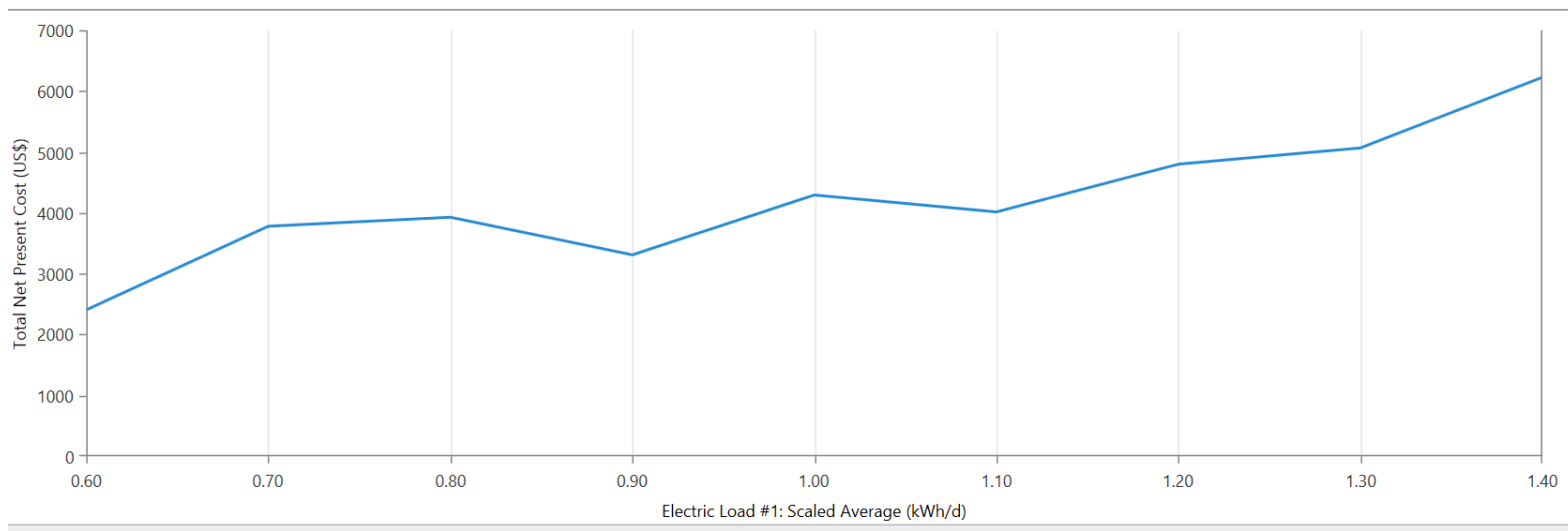

Fig. 10. Line plot with NPC for remote Edo community for $4.63 \mathrm{kWh} / \mathrm{m}^{2} /$ day solar scaled average.

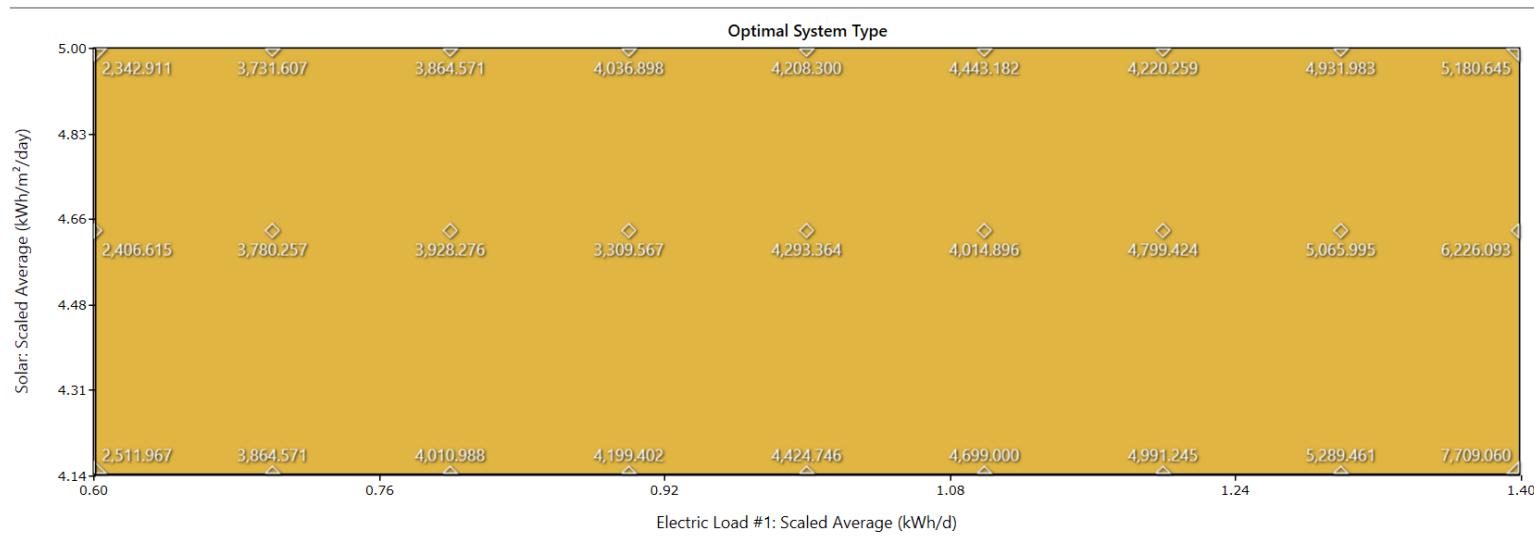

Fig. 11. Optimization surface plot with NPC for $4.14 \mathrm{kWh} / \mathrm{m}^{2} /$ day solar scaled average.

Fig. 10 represents the graph for total Net present Cost (NPC) against Electrical load for $4.63 \mathrm{kWh} / \mathrm{m}^{2} /$ day solar scaled average. The result shows that as the load increases, there in a non-linear increase in system cost. this is because with increase in load demand comes an increase in the required components needed to meet the demand of the system. result for solar scaled average of $4.14 \mathrm{kWh} / \mathrm{m}^{2} /$ day and $5.00 \mathrm{kWh} / \mathrm{m}^{2} /$ day also shows similar results.

Fig. 11 above is a plot of solar scaled average against average electrical load. this graph shows that if solar energy is more, then system cost is going to be low. For instance, in the case of $0.6 \mathrm{kWh} / \mathrm{d}$, the NPC of the system at $4.14 \mathrm{kWh} / \mathrm{m}^{2} /$ day is $\$ 2,511.967$, whereas at a solar scaled average of $5.00 \mathrm{kWh} / \mathrm{m}^{2} /$ day the NPC is $\$ 2,342.911$, this shows a decrease in cost of about $\$ 170$. For electrical load of $0.90, \mathrm{NPC}$ at $4.14 \mathrm{kWh} / \mathrm{m}^{2} /$ day is $4,199.402$, whereas at 5.00 the NPC reduces to $\$ 4,036.898$.

\section{CONCLUSION}

The study involved the sizing of a remote community in Edo State, Nigeria having 9 houses located far away from the utility grid and the city. The cost of running electric cables to connect this remote community to the city utility grid would be far more expensive and would lead to huge losses along the line, which would be counterproductive. For this research, 
solar energy was considered due to the abundance in the supply of solar resources in the region. From simulated results a PV microgrid DC system is the best solution in terms of cost and optimization of energy. Factors such as variation in solar resources, unequal use of energy in the community can be balanced out by sharing excess energy among residents in the community. With an increase or decrease in solar irradiation from $4.14 \mathrm{kWh} / \mathrm{m}^{2} /$ day to $5 \mathrm{kWh} / \mathrm{m}^{2} /$ day due to climatic factors, there would be little to no change in system cost because houses that have less energy consumption will share excess energy with a residence with more need for energy. This system is far better than a standalone system for each resident as it would require much more PV components leading to more cost in installation, operation, and maintenance.

\section{REFERENCES}

[1] A.I Malakani et al. Study and Design of off-grid PV power system in Pririen, Asmat Regency, Papua province using Matlab/Simuink. $2^{\text {nd }}$ International Conference on High Voltage Engineering and Power Systems (ICHVEPS), 2019.

[2] A. Chauhan, R.P Saini. A review on integrated renewable energy system based power generation for stand-alone applications: configurations, storage options, sizing methodologies and control. Renewable and Sustainable Energy Reviews, 2014;38:99-120.

[3] Linda Faridah. Tesis: Studi Dan Desain Sistem Pembangkit Listrik Hybrid off-grid untuk beban komunal dan deban administratif Di3 Wilayah Maluku Indonesia. Institut Teknologi Bandung, 2017.

[4] Alpesh Desai. Exploring Technical and economic feasibility of a standalone solar PV based DC distribution system over AC for use in houses. $47^{\text {th }}$ IEEE Photovoltaic Specialists Conference (PVSC), 2020.

[5] Adithya Rajeev, K. Shanmukha. Design of an off-grid PV system for the rural community. International conference on Emerging Trends in Communication., Control, Signal Processing and Computing Applications (C2SPCA), 2013.

[6] S. Sini, Achala Jain. Techno-economic feasibility analysis of a solar off-grid system for a residential load in an under-developed colony. International conf. on Recent innovations in Electrical, Electronics \& Communication Engineering (ICRIEECE), 2018.

[7] Nunu Mazibane, S.P Chowdhury, A.T Zau, M.J. Malatji. Design of an off-grid PV system for Mapetja rural village. IEEE AFRICON, 2019.

[8] C.E Lin, B.C Phan, Y-Chih Lai. Optimal design of hybrid renewable energy system using Homer: A case study in the Philippines. IEEE Southeastcon, 2019.

[9] C.B Muzaffar, M.T. Tariq. Design and analysis of off grid solar system for DC load of a house in Pakistan. IEEE IEMCON, 2020.

[10] A.U Rehman, M.T. Iqbal. Design of an off-grid solar system for a rural house in Pakistan. IEEE IEMCOM, 2020.

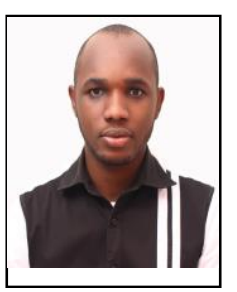

Japhet Chikanka Ozogbuda was born on $16^{\text {th }}$ of August 1993 in Rumukwurushi, Port Harcourt, Rivers State, Nigeria. He graduated from Rivers State University, Port Harcourt, Nigeria in Electrical Engineering (B. Tech) by 2017. He is a graduate student and doing a research based $\mathrm{M}$. Eng in Electrical Engineering at Memorial University of Newfoundland, Canada.

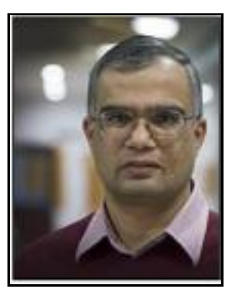

M. Tariq Iqbal received the B.Sc. (EE) degree from the University of Engineering and Technology, Lahore in 1986, the M.Sc. Nuclear Engineering degree from the Quad-e-Azan University, Islamabad in 1988, and the Ph.D. degree in Electrical Engineering from the Imperial College London in 1994. Since 2001 he is working at the Faculty of Engineering and Applied Science. Memorial University of Newfoundland. Presently he is full professor. His teaching activities cover a range electrical engineering topic, including renewable energy systems and power electronics. Currently, his research focuses on modeling and control of hybrid energy system. 